\title{
Applying Plant Hydraulic Physiology Methods to Investigate Desiccation During Prolonged Cold Storage of Horticultural Trees
}

\section{OPEN ACCESS}

Edited by:

Thorsten M. Knipfer, University of British Columbia, Canada

Reviewed by:

Tom De Swaef,

Institute for Agricultural, Fisheries and Food Research (ILVO),

Belgium

Claudia Cocozza,

University of Florence, Italy

*Correspondence:

Rebecca A. Sheridan Rebecca.Sheridan@Weyerhaeuser. Lloyd.Nackley@OregonState.edu

Specialty section: This article was submitted to

Plant Abiotic Stress,

a section of the journal

Frontiers in Plant Science

Received: 19 November 2021 Accepted: 01 February 2022

Published: 24 February 2022

Citation:

Sheridan RA and Nackley LL (2022) Applying Plant Hydraulic Physiology Methods to Investigate Desiccation During Prolonged Cold Storage of Horticultural Trees.

Front. Plant Sci. 13:818769. doi: 10.3389/fpls.2022.818769

\author{
Rebecca A. Sheridan ${ }^{1 *}$ and Lloyd L. Nackley ${ }^{2,3 *}$
}

${ }^{1}$ Weyerhaeuser, Federal Way, WA, United States, ${ }^{2}$ North Willamette Research and Extension Center, Oregon State University, Corvallis, OR, United States, ${ }^{3}$ Department of Horticulture, Oregon State University, Corvallis, OR, United States

Plant nursery production systems are a multi-billion-dollar, international, and horticultural industry that depends on storing and shipping live plants. The storage environment represents potentially desiccating and even fatal conditions for dormant, bareroot, and deciduous horticulture crops, like orchard trees, forestry trees, ornamental trees, and grapevines. When tree mortality is considered within a plant hydraulic framework, plants experiencing water stress are thought to ultimately die from hydraulic failure or carbon starvation. We hypothesized that the hydraulic framework can be applied to stored crops to determine if hydraulic failure or carbon starvation could be attributed to mortality. We used deciduous trees as model species because they are important horticultural crops and provide a diversity of hydraulic strategies. We selected cultivars from six genera: Acer, Amelanchier, Gleditsia, Gymnocladus, Malus, and Quercus. For each cultivar, we measured stem hydraulic conductance and vulnerability to embolism. On a weekly basis for 14 weeks (March-June), we removed trees of each cultivar from cold storage $\left(1-2^{\circ} \mathrm{C}\right)$. Each week and for each cultivar, we measured stem water potential and water content $(n=7)$ and planted trees to track survival and growth $(n=10)$. At three times during this period, we also measured non-structural carbohydrates. Our results showed that for four cultivars (Acer, Amelanchier, Malus, and Quercus), the stem water potentials measured in trees removed from storage did not exceed stem $P_{50}$, the water potential at which $50 \%$ of stem hydraulic conductivity is lost. This suggests that the water transport system remains intact during storage. For two cultivars (Gleditsia and Gymnocladus), the water potential measured on trees out of storage exceeded stem $P_{50}$, yet planted trees from all weeks survived and grew. In the 14 weeks, there were no significant changes or directional trends in stem water potential, water content, or NSC for most cultivars, with a few exceptions. Overall, the results show that the trees did not experience detrimental water relations or carbon starvation thresholds. Our results suggest that many young deciduous trees are resilient to conditions caused by prolonged dormancy and validate the current storage methods. This experiment provides an example of how a mechanistically based understanding of physiological responses can inform cold storage regimes in nursery tree production.

Keywords: arboriculture, chilling hours, water relations, non-structural carbohydrates, nursery management, urban forestry, vulnerability curves 


\section{INTRODUCTION}

The plant nursery industry produces billions of plants and trees, which are then shipped to global destinations (Haase et al., 2020). Making them unique among crops, plants grown in nursery production systems are often moved great distances in the middle of their lifecycle, which generates novel physiological stress to these otherwise stationary lifeforms. For this to be feasible, nursery professionals take advantage of natural phenophases, for example, harvesting and transferring dormant deciduous species. Many plant nurseries (hereafter referred to as nurseries) are located where favorable conditions and consistent seasonal cues induce winter dormancy. A wide variety of orchard species, forestry species, and ornamental species are produced in a nursery production system known as "bareroot" in which trees are excavated (aka "lifted") in late fall and winter, stored at or just below freezing temperatures during winter, and shipped in the spring. Plants grown and sold in nursery systems must be able to withstand prolonged storage conditions without significant detrimental effects on growth and survival after planting (Maclennan and Fennessy, 2006; Dumroese et al., 2016). Decades of commercial trial and error have created rough guidelines for safe storage practices for bareroot plants. However, there is a need for relevant, mechanistic information about how long trees can tolerate cold storage without damage or death. We believe that investigating the impacts of desiccation and carbon depletion in cold storage through a plant hydraulic framework will help provide meaningful guidelines to this multi-billion-dollar annual industry (United State Department of Agriculture, 2020).

How long seedlings can be kept in cold storage is one of the key physiological questions for optimizing nursery production (Grossnickle et al., 2020). For example, more time in storage allows for the accumulation of chilling hours, which can lead to faster bud break and increased root growth after planting (Harris et al., 1993; Nanninga et al., 2017). The two key risks of storage are desiccation and carbon starvation due to respiration, in the absence of external causes of mortality, such as pests and pathogens (Mckay, 1997). Winter desiccation can impact performance in the growing season if the hydraulic function cannot be restored (Niu et al., 2017). Dormant trees rely on carbohydrate reserves for respiration and tissue development (Tixier et al., 2019). The physiological effects of cold storage have been well studied for conifer seedlings but are not understood as well for deciduous trees (Ritchie, 1982; Cannell et al., 1990; McKay, 1994). Developing parameters such as the length of time deciduous trees will tolerate cold storage conditions without a loss of plant vigor requires careful evaluation of multiple physiological traits (Jacobs et al., 2008). Even then, recommendations may vary by species and by variety or ecotype within species (Overton et al., 2013). Decisions about planting windows to avoid frost damage and ensure access to the planting site are made all the more difficult due to the unpredictable impacts of climate change (Chmura et al., 2011; Fargione et al., 2021). Nursery professionals may need to keep trees in cold storage for longer than is the current practice to respond dynamically to a changing climate.
A framework of tree mortality that considers the trade-offs between hydraulic failure and carbon starvation has been considered extensively (Sevanto et al., 2014; Adams et al., 2017). This "hydraulic framework" has been applied to explain tree mortality as a result of drought (Choat et al., 2018). Plant water relations and xylem function are typically studied in actively growing (i.e., non-dormant) seedlings and trees (Landsberg and Waring, 2017). However, the same physiological processes are important for the survival of dormant deciduous trees: the combined effects of water stress and low carbohydrate reserves can compromise winter cold tolerance, leading to a greater likelihood of mortality (Galvez et al., 2011). Water relations and carbon balance and the interactions of these fluxes coming out of the winter are also important to ensure function in the next growing season (Améglio et al., 2004; Tomasella et al., 2017).

Nursery production systems that use cold storage provide a unique opportunity to study the confounding physiological challenges that trees face through winter. Given the prevalence of cold storage in nursery production, it is important to understand the plant responses to develop research-based management practices that maintain plant health. Therefore, our objectives were to examine the patterns of plant water relations and NSC dynamics during storage for cultivated varieties (cultivars) of six genera of deciduous trees, Acer, Gleditsia, Gymnocladus, Malus, and Quercus. We selected these six genera as model species because they are high value and widely sold horticultural crops and provide a diversity of hydraulic strategies. We wanted to identify if these trees reach physiological thresholds that correlate with mortality during extended cold storage. If so, would the impacts from cold storage be evident in post-planting performance?

We had the following expectations for the plant physiological metrics that we measured in this experiment: stem water potential and stem water content would decline over an extended time in cold storage due to desiccation. Total stem NSC would also decline over time in cold storage, due to respiration. As a result of the compound impacts of desiccation and carbon depletion due to extended time in cold storage, height growth after outplanting would be diminished for trees that were in storage longer. In trees where the stem water potential dropped low enough to cause significant hydraulic failure in the xylem, we expected growth and survival after planting would be negatively affected.

\section{MATERIALS AND METHODS}

Starting March 19, 2020, we obtained trees from the cold storage facility at a commercial shade tree nursery in Canby, Oregon $(45.21,-122.73)$. Retrieving trees from the storage facility continued every week until June 18,2020 , for a total of 14 weeks. The stored trees had been harvested in fall 2019 and washed of all soil in a process called bare-rooting. While in cold storage, the trees were stored at $1-2^{\circ} \mathrm{C}$. The coolers were turned off the week of June 8, 2020. Each week, we transported the trees to Oregon State University's North 
Willamette Research and Extension Center (NWREC) in Aurora, Oregon (45.28, -122.75) for sampling and planting. Upon arrival at NWREC, we randomly sorted the trees into planting and destructive sampling cohorts. Ten trees were planted each week. For each of the seven trees selected for destructive sampling, we measured stem water potential, water content for the terminal stem segment, and non-structural carbohydrates in the terminal stem segment.

We evaluated six cultivars: Red Sunset ${ }^{\circledR}$ maple (Acer rubrum "Franksred"); Prairie fire crabapple (Malus "Prairifire"); red oak (Quercus rubra); Skyline ${ }^{\circledR}$ honeylocust (Gleditsia triacanthos "Skycole"); Autumn Brilliance ${ }^{\circledR}$ serviceberry (Amelanchier $x$ grandiflora); and Kentucky coffeetree (Gymnocladus dioicus). Due to logistical challenges, not all cultivars were planted at all weeks; additional details and planting and sampling timing can be found in Table 1 .

\section{Planting and Field Measurements}

Each week, we planted 10 trees in a field at NWREC. The field has loam soil ( $47 \%$ sand; $32 \%$ silt; and $21 \%$ clay). Depending on the exact size of the weekly shipment, three to seven of the trees planted had the terminal shoot removed for other measurements described below; the remaining trees were planted without any pruning. We measured height at planting, and again on November 30, 2020, and calculated the incremental growth. Additionally, we monitored mortality and phenological development after planting.

\section{Environmental Conditions}

Temperature and precipitation were tracked by an U.S. Bureau of Reclamation AgriMet weather station that is located adjacent to the field and displayed in Figure 1 (AgriMet, 2016). Drip irrigation was installed within several weeks of each planting to mitigate any impacts of drought. By June 30, 2020, all trees were on drip irrigation.

\section{Physiological Measurements}

Physiological measurements were made on seven individuals of each cultivar at each transplanting date.

\section{Stem Water Potential}

We measured midday stem water potential on the terminal shoot using a pressure chamber (Model 1505D-EXP, PMS Instruments, Albany, OR). Stem water potential can be reliably measured on dormant deciduous trees and used to track winter water stress (Milliron et al., 2018).

\section{Water Content}

We calculated the water content of the plant tissue using the following equation:

$$
W C\left(\frac{g}{g}\right)=\frac{\text { Fresh Weight }- \text { Dry Weight }}{\text { DryWeight }}
$$

For stem water content, we weighed the same terminal stem segment used in the water potential measurements. Immediately after the stem water potential measurement, we put the stem segment into a plastic bag until measuring the fresh weight. We then dried the plant tissues in a drying oven at $75^{\circ} \mathrm{C}$ for 7 days, then weighed the samples.

\section{Non-structural Carbohydrates:}

Samples of the same stem segments used for water relations measurements were also used to analyze non-structural carbohydrates (NSC) by a lab at Oregon State University that specializes in this type of analysis. To extract the NSC, the samples were ground to a fine powder in a Wiley mill. The soluble carbohydrates were extracted in deionized water; starch was extracted with ethanol and an A-AMG (amyloglucosidase) enzyme solution. NSC content of the samples was quantified by measuring absorbance at $630 \mathrm{~nm}$ using a microplate multiscan reader (Leyva et al., 2008).

\section{Stem Hydraulic Conductance and Vulnerability Curves}

We measured stem hydraulic conductance and vulnerability to embolism on three samples for each of the species, except Quercus. We cut a stem segment of approximately $20 \mathrm{~cm}$, less

TABLE 1 | Cultivated species (cultivars) represented within this experiment and the corresponding dates for planting and NSC sampling.

\begin{tabular}{|c|c|c|c|c|c|c|}
\hline Species & Cultivar name & Stock type & First planting date & $\begin{array}{l}\text { Mid-season NSC } \\
\text { sample date }\end{array}$ & Last planting date & Xylem anatomy \\
\hline Acer rubrum 'Franksred' & Red Sunset ${ }^{\circledR}$ maple & $\begin{array}{l}\text { 4-foot whips; 4- and } \\
\text { 5-foot branched } \\
\text { saplings }\end{array}$ & March 19, 2020 & April 30, 2020 & June 18, 2020 & Diffuse porous \\
\hline $\begin{array}{l}\text { Amelanchier } x \text {. } \\
\text { grandiflora }\end{array}$ & $\begin{array}{l}\text { Autumn Brilliance } \\
\text { serviceberry }\end{array}$ & 3- and 4-foot whips & April 2, 2020 & April 30, 2020 & May 21, 2020 & Diffuse porous \\
\hline $\begin{array}{l}\text { Gleditsia triacanthos } \\
\text { 'Skycole' }\end{array}$ & Skyline ${ }^{\circledR}$ honeylocust & 3- and 4-foot whips & March 19, 2020 & April 30, 2020 & May 21, 2020 & Ring porous \\
\hline Gymnocladus dioicus & Kentucky coffeetree & 4-foot whips & April 2, 2020 & April 30, 2020 & May 28, 2020 & Ring porous \\
\hline Malus 'Prairifire' & Prairie fire crabapple & $\begin{array}{l}5 \text {-foot whips on hardy } \\
\text { rootstock }\end{array}$ & March 19, 2020 & April 30, 2020 & May 21, 2020 & Diffuse porous \\
\hline Quercus rubra & Red oak & 4-foot whips & March 19, 2020 & April 30, 2020 & June 18, 2020 & Ring porous \\
\hline
\end{tabular}

Planting dates vary due to logistical issues that differed by cultivar. Xylem anatomy is also listed (InsideWood, 2004; Wheeler, 2011). 


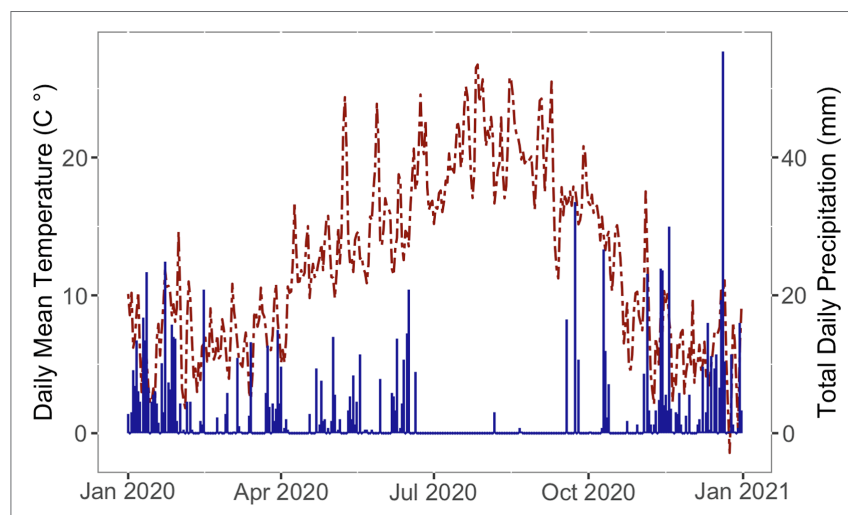

FIGURE 1 | Daily mean temperature (left axis, red dashed line) and total daily precipitation (right axis, blue solid line) at the planting location over the first growing season after planting.

TABLE 2 | Vulnerability curve parameters for five cultivars. Stem $P_{12}, P_{50}$, and $P_{88}$ are modeled from the vulnerability curves shown in Figure $\mathbf{2}$

\begin{tabular}{lcccc}
\hline & Stem $\boldsymbol{P}_{\mathbf{x}}$ & Estimate & \multicolumn{2}{l}{$\mathbf{9 5 \%}$ Confidence Interval } \\
\hline \multirow{2}{*}{ Acer } & $P_{12}$ & -1.37 & -1.12 & -1.61 \\
& $P_{50}$ & -2.52 & -2.34 & -2.69 \\
Amelanchier & $P_{88}$ & -3.77 & -3.42 & -4.24 \\
& $P_{12}$ & -1.70 & -1.21 & -2.21 \\
\multirow{3}{*}{ Gleditsia } & $P_{50}$ & -4.53 & -4.16 & -4.97 \\
& $P_{88}$ & -8.66 & -7.24 & -11.38 \\
Gymnocladus & $P_{12}$ & & & \\
& $P_{50}$ & -0.33 & -0.26 & -0.40 \\
& $P_{88}$ & -0.70 & -0.57 & -0.88 \\
Malus & $P_{12}$ & & & $\mathrm{NA}$ \\
& $P_{50}$ & -0.60 & $\mathrm{NA}$ & $\mathrm{NA}$ \\
& $P_{88}$ & -0.75 & $\mathrm{NA}$ & -1.95 \\
& $P_{12}$ & -1.67 & -1.40 & -3.76 \\
& $P_{50}$ & -3.56 & -3.36 & -6.51
\end{tabular}

$N=3$ for each cultivar. For Gleditsia and Gymnocladus, the stem $P_{50}$ was higher than $-1 \mathrm{MPa}$ and $P_{12}$ was not estimated from the collected data.

than $15 \mathrm{~mm}$ in diameter (small enough to fit the cavitation chamber), and without side branches from the middle of the tree. The initial cuts were made underwater because the unplanted trees could be laid within a basin of water. We immediately brought the stem segments into the lab, removed the bark, and recut the ends underwater. We then vacuum infiltrated stems overnight in $0.2 \mu \mathrm{m}$ filtered deionized water to remove initial emboli.

\section{Stem-Specific Conductivity}

We measured stem conductance using the gravity-feed method with $0.2 \mu \mathrm{m}$ filtered deionized water. We measured flow through the stem using an electronic balance (Explorer Ex224, Ohaus Corp., Parsippany, NJ) connected to a computer running the R-based program conductR (Smith, 2018). When the flow rate stabilized, we recorded flow as the average of the last four readings. To calculate hydraulic conductivity, we used the slope of the volume flow rate $\left(\mathrm{kg} \mathrm{s}^{-1}\right)$ vs. the pressure gradient
$\left(\mathrm{MPa} \mathrm{m}^{-1}\right)$; then, to standardize to stem-specific conductivity, the hydraulic conductivity was divided by stem cross-sectional area $\left(k_{\mathrm{s}}, \mathrm{kg} \mathrm{m}^{-1} \mathrm{~s}^{-1} \mathrm{MPa}^{-1}\right)$.

\section{Vulnerability to Embolism}

We used the air-injection method to measure stem vulnerability to embolism (Sperry and Saliendra, 1994). After the maximum stem conductivity was measured as described above, we inserted the stem segment into the cavitation chamber accessory for the PMS pressure chamber and pressurized for $10 \mathrm{~min}$. After there were no longer bubbles exiting the stem due to pressurization, flow through the stem was measured again. The pressure was increased by $0.25 \mathrm{MPa}$ intervals for Gleditsia and Gymnocladus and $0.5 \mathrm{MPa}$ intervals for the other four cultivars. In between each pressure interval, stem-specific conductivity was again measured. Using conductR, the percent loss of stem-specific conductivity relative to maximum was plotted against the pressure applied by the pressure chamber to create vulnerability. We increased pressures in the cavitation chamber until $90 \%$ of stem-specific conductivity was lost, so the maximum pressurization varied for each cultivar. Vulnerability curves and water potential thresholds at which 12, 50, and $88 \%$ of stem-specific conductivity were lost $\left(P_{12}, P_{50}, P_{88}\right)$ were modeled using the R package fitPLC (Duursma and Choat, 2017).

\section{Statistical Analysis}

Each cultivar was analyzed separately for several reasons: the trees came from different nursery sources, the range of planting dates varied by species, and in a few cases, the sample size varied by species at planting. To test if there was a linear relationship between the week of planting and the plant physiological metrics, we used linear regression. The four physiological metrics, which were tested individually, were as: stem water potential, stem water content, total stem NSC, and height growth after planting. We used the software $\mathrm{R}$ version (4.0.2) for all statistical analyses.

\section{RESULTS}

The year 2020 started with warmer than average temperatures (Figure 1). By March 19th, when planting began, temperature closely followed the 30 year average [U.S.A. National Phenology Network (NPN), 2020]. In this region, most rainfall occurs from October through June, with a dry period from July to September. The region in which this project is located experienced moderate to severe drought conditions during the experiment (U.S. Drought Monitor, 2021). The trees were irrigated through the summer dry period.

Stem $P_{12}, P_{50}$, and $P_{88}$, as estimated from the vulnerability curves are reported in Table 2 . Stem vulnerability curves showed two types of responses (Figure 2). Gleditsia and Gymnocladus demonstrated vulnerability to embolism at relatively mild water potentials (>-2.0 MPa). Acer, Amelanchier, and Malus were not as susceptible to embolism until more extreme water potentials $(<-2.0 \mathrm{MPa})$. We did not build hydraulic vulnerability curves for the Quercus cultivar in this experiment due to the 
methodological challenges associated with hydraulic conductivity measurements with Quercus stems (Cavender-Bares and Holbrook, 2001). For this analysis, we use previously reported stem $P_{50}$ values for Q. rubra $\left(P_{50}=-2.5 \mathrm{MPa}\right.$; Cochard and Tyree, 1990).

For one cultivar., Amelanchier, there was evidence of a significant negative effect of planting week on stem water

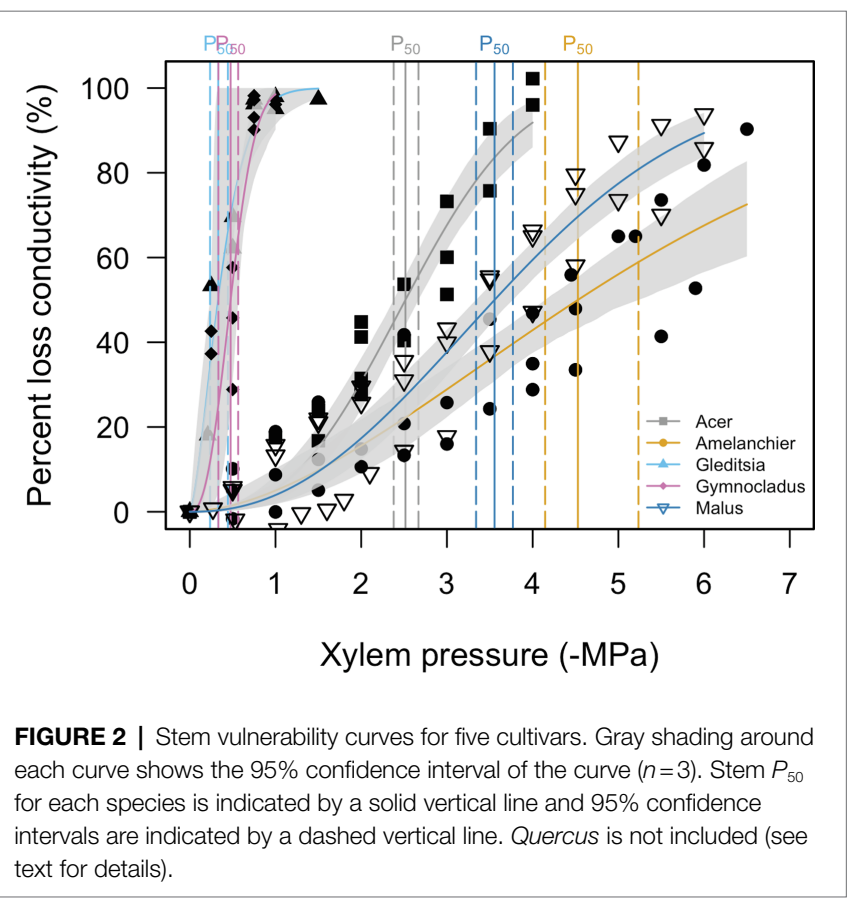

potential $\left(\beta=-0.22, F_{1,51}=35.84, p<0.01\right.$; Figure 3). Amelanchier was the cultivar we had the most logistical issues with procuring, so the effect is evaluated over only 8 weeks. Amelanchier also had the most negative stem $P_{50}$, so despite a decline in stem water potential over time in cold storage, measured stem water potentials did not come close to exceeding stem $P_{50}$ in the time frame we tested. For all other cultivars, there was no evidence of a significant effect of planting week on stem water potential (Table 3). Two cultivars-Gleditsia and Gymnocladushad stem water potentials that exceeded stem $P_{50}$ from the very first week of the experiment. For Acer, Amelanchier, Malus, and Quercus, median stem water potential did not exceed stem $P_{50}$.

For all six cultivars, there was no evidence of a significant effect of the planting dates in the stem water content (Figure 4). The parameters of the linear regression model are given in Table 3. Stem water content is expressed in grams of water in fresh tissue to grams of dry plant tissue; with most stem water content values falling around or above $1 \mathrm{~g} / \mathrm{g}$, this indicates that the fresh tissue is over $50 \%$ water content, by weight.

Based on the expectation that total NSC would diminish over time in storage due to respiration, we evaluated the effect of the week of removal from cold storage and planting on total NSC concentration (mg/g DW). There was evidence of a significant positive effect of planting week on total NSC for Amelanchier $\left(\beta=8.21, F_{1,16}=9.43, p<0.01\right)$. In contrast, for Gymnocladus, there was evidence of a significant negative effect of planting week on total NSC $\left(\beta=-16.68, \mathrm{~F}_{1,19}=5.40\right.$, $p<0.05)$. There was no evidence of a significant effect of planting week on total NSC for the other cultivars (Table 3). Among the cultivars, there was no clear pattern of a shift

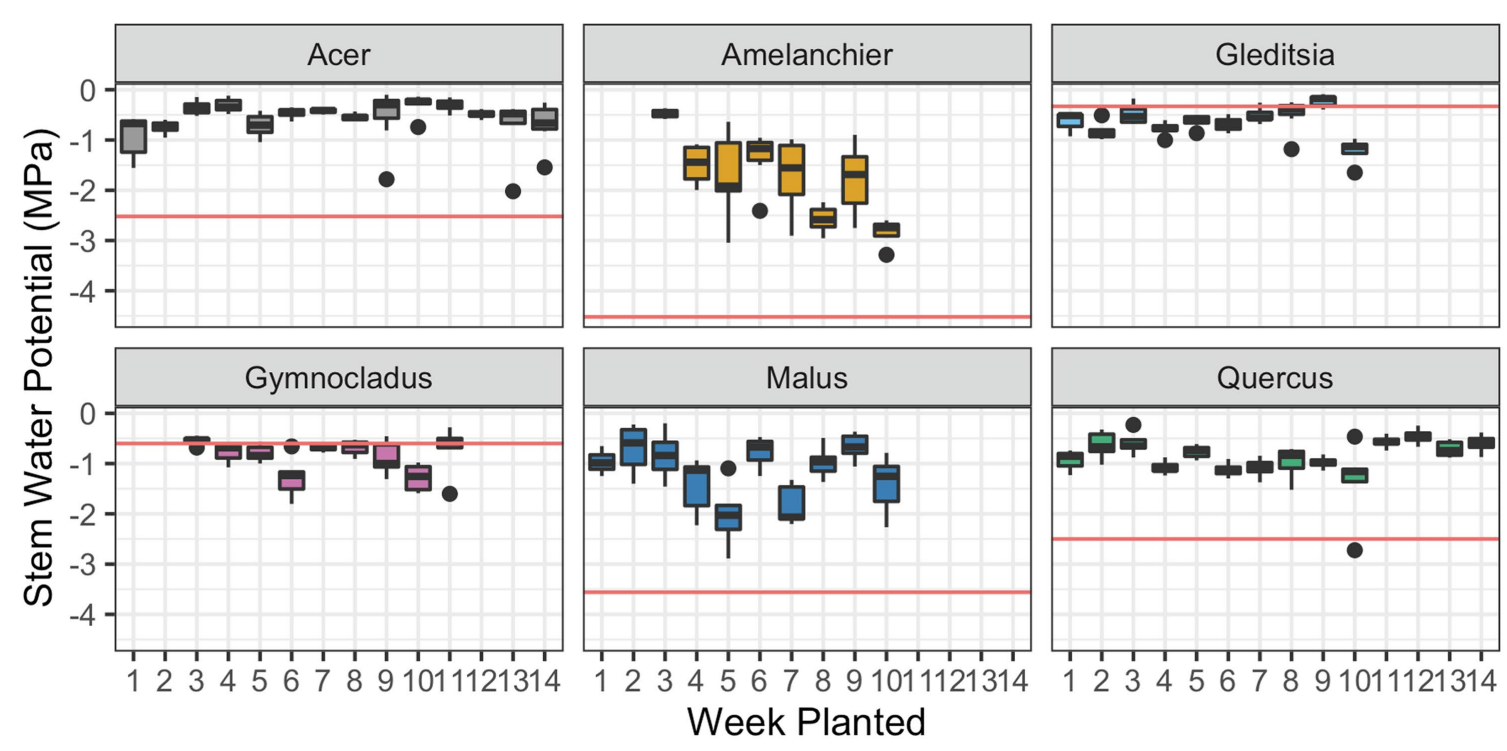

FIGURE 3 | Stem water potential at the time of removal from cold storage and subsequent planting. Box plots show median, interquartile range, and minimum and maximum range for each week of planting. Solid red lines indicate stem $P_{50}$ for each species, estimated by the stem vulnerability curves. There was evidence of a significant negative effect of planting date on stem water potential for Amelanchier ( $<<0.01$; details in text and Table 3). For all other cultivars, there was no evidence of a significant effect of planting date on stem water potential. 


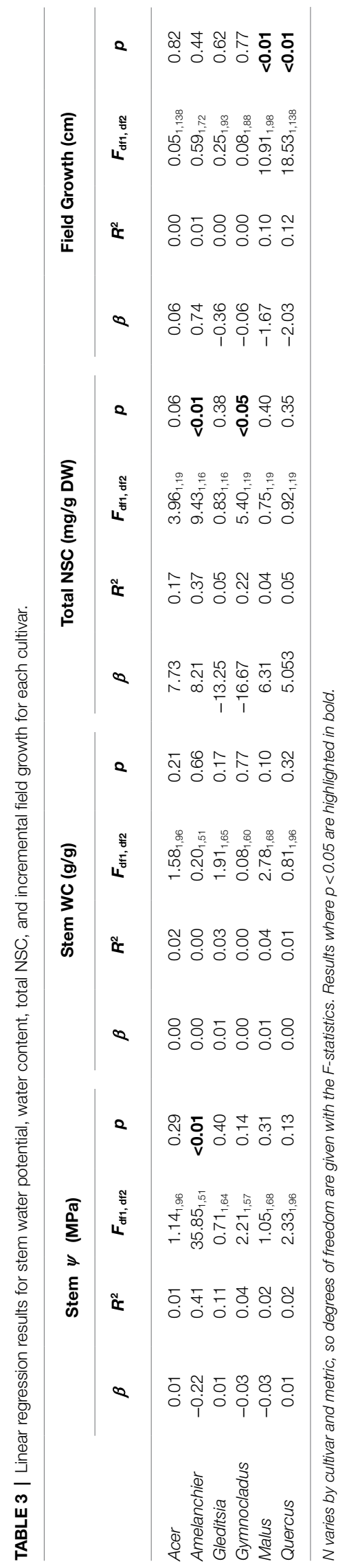

between starch concentration and soluble sugars concentration (Figure 5).

In the case of four out of six of the cultivars, there was no significant effect of the planting date on the height growth in the season that followed planting (Figure 6; Table 3). There was evidence of a significant negative effect of planting date on height growth for Malus $\left(\beta=-1.67, \mathrm{~F}_{1,98}=10.91, p<0.01\right)$ and Quercus $\left(\beta=-2.03, F_{1,138}=18.53, p<0.01\right)$. The significant effect of planting date on height in these cultivars is driven by the absence of height growth in the latest-planted trees. Additionally, we observed frequent terminal stem die-back in planted Malus. However, there was not a higher incidence of mortality at the later planting dates. We observed that bud flush followed the timing of planting. None of the cultivars had broken bud in cold storage, but the Acer trees had bloomed in storage before the first planting date. At the end of the growing season, we observed that leaf senescence occurred across a gradient, beginning several days earlier in the earlyplanted trees than the late-planted trees.

\section{DISCUSSION}

Contrary to previous work, we did not observe the effects of extended cold storage on growth after planting for most of the cultivars we tracked in this experiment. For two cultivars, Malus and Quercus, there was a negative relationship between the timing of planting and incremental height growth, but this could not be tied to a change in water relations or carbon depletion. For all cultivars, survival was high when the trees were planted into an irrigated, weeded environment. The managed planting site probably helped tree performance: stressful environmental conditions at the planting site are more likely to expose detrimental impacts from the nursery production process (Grossnickle et al., 2020). However, the consistent height growth in the field helps to rule out other detrimental effects of extended storage on physiological traits that we did not measure within the experiment. The range of planting dates tested in this experiment extended from the operational standard, in early to mid-spring, to beyond what commercial growers would consider feasible, at the beginning of summer. In other research, extended time in cold storage and desiccation during storage have been tied to poor outplanting performance and changes in physiology for nursery-grown plants (Tung et al., 1986; Deans et al., 1990; Mena-Petite et al., 2001; Overton et al., 2013).

We expected that trees with a stem water potential that exceeded $P_{50}$ or more in storage would have detrimental effects on growth and survival after planting. Hydraulic failure occurs when there is extensive xylem embolism, which reduces a stem's capacity to conduct water. For angiosperm species, lethal water potentials correlated with $80-100 \%$ loss of xylem hydraulic conductance (PLC; Choat et al., 2018). Short of catastrophic hydraulic failure, chronically high PLC (e.g., $\mathrm{P}_{60}$ ) may also precede mortality (Sperry and Love, 2015). Therefore, $P_{50}$ is a conservative threshold for stem water potentials beyond which we might expect to see detrimental effects to plant growth 

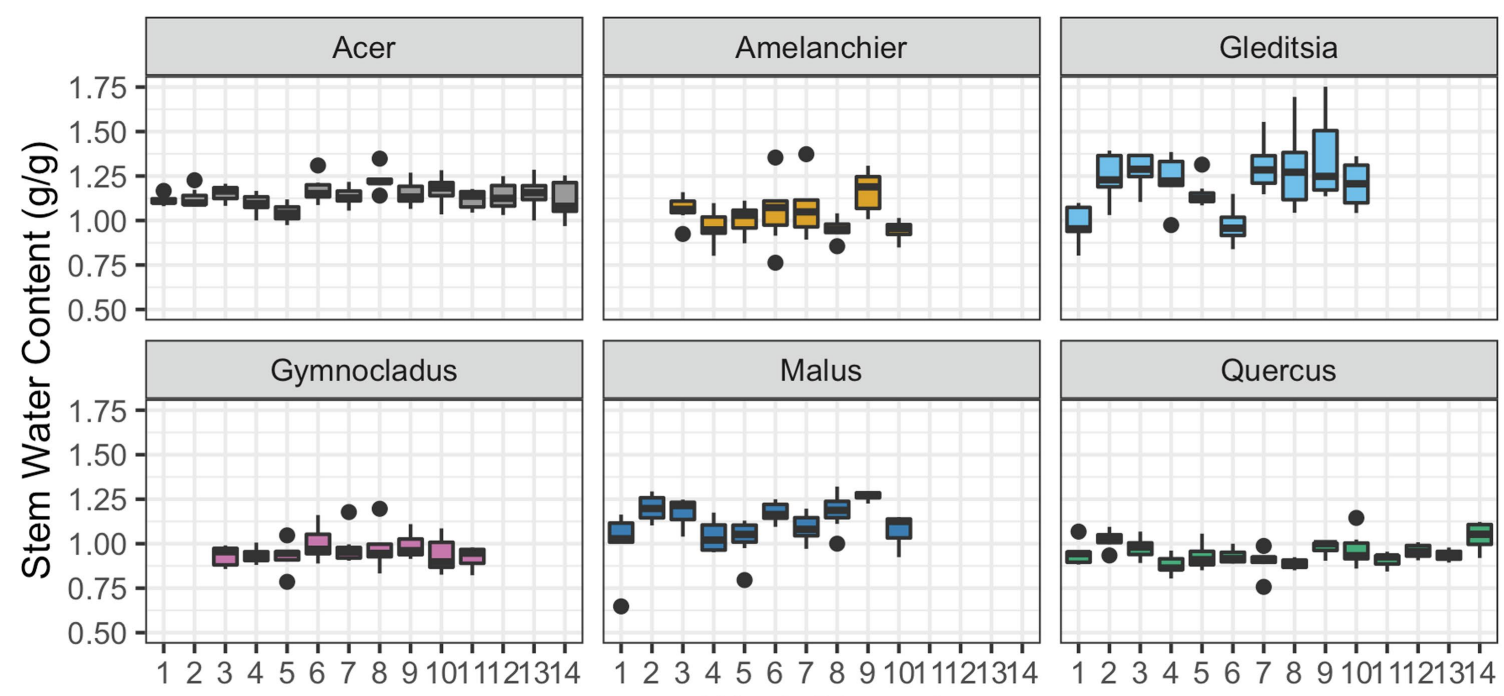

Week Planted

FIGURE 4 | Stem water content at the time of removal from cold storage and subsequent planting. Box plots show median, interquartile range, and minimum and maximum range for each week of planting. One outlier for Gleditsia has been removed in this figure, but not the statistical analysis. There was no evidence of a significant effect of planting date on stem water content for any cultivar.
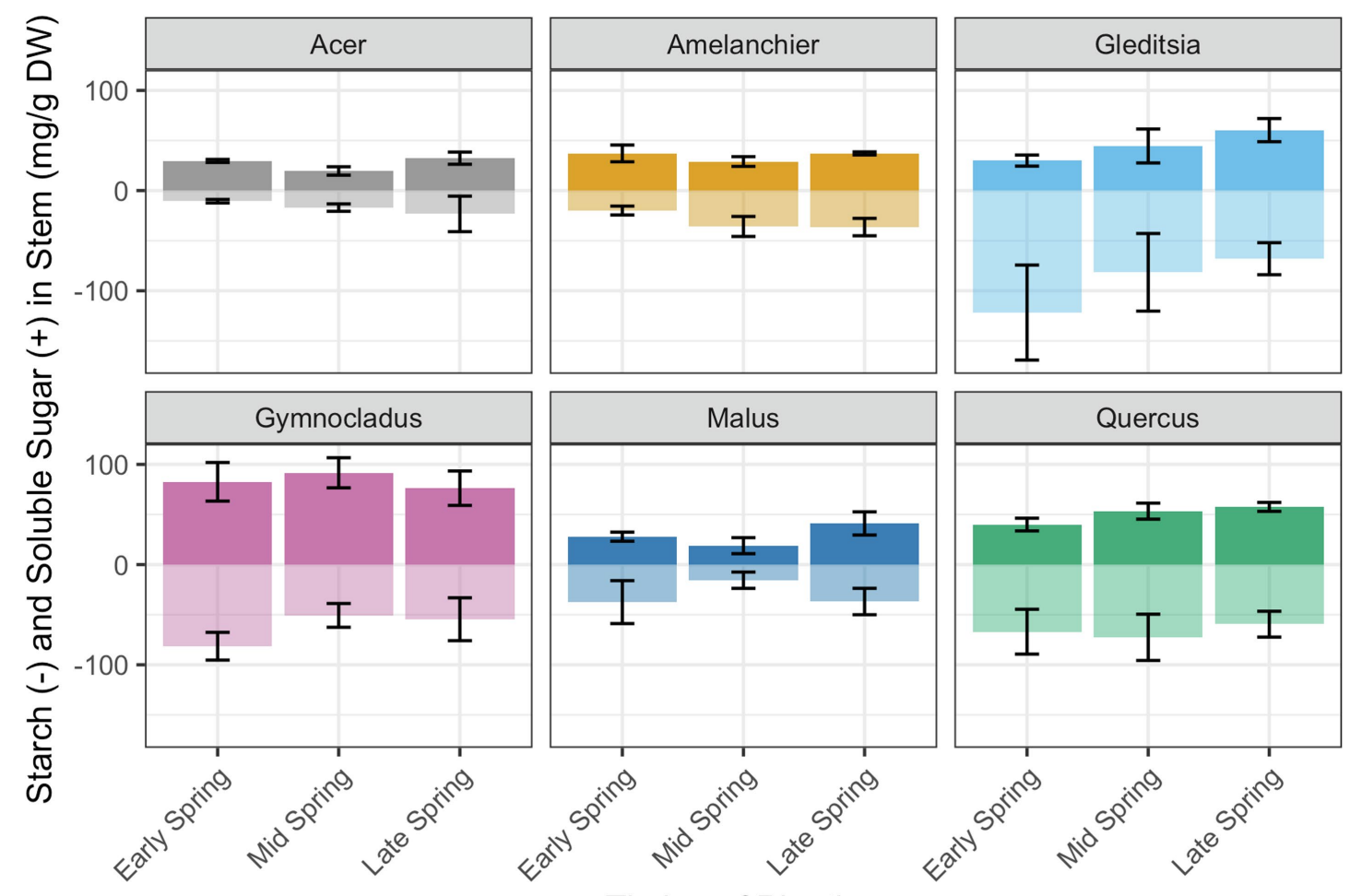

Timing of Planting

FIGURE 5 | Total non-structural carbohydrate concentration and relative proportion of starch (transparent bars, below midline) and soluble sugars (solid bars, above midline). The specific dates for the timing of planting categories are in Table 1. There was evidence of a significant positive relationship of planting week on total NSC concentration for Amelanchier ( $p<0.01$; details in text and Table 1) and evidence of a significant negative relationship for Gymnocladus ( $p<0.05$; details in text and Table 1). Error bars indicate standard deviation for soluble sugar and starch concentration separately. Soluble sugars and starch concentrations were not tested separately in linear regression models. 


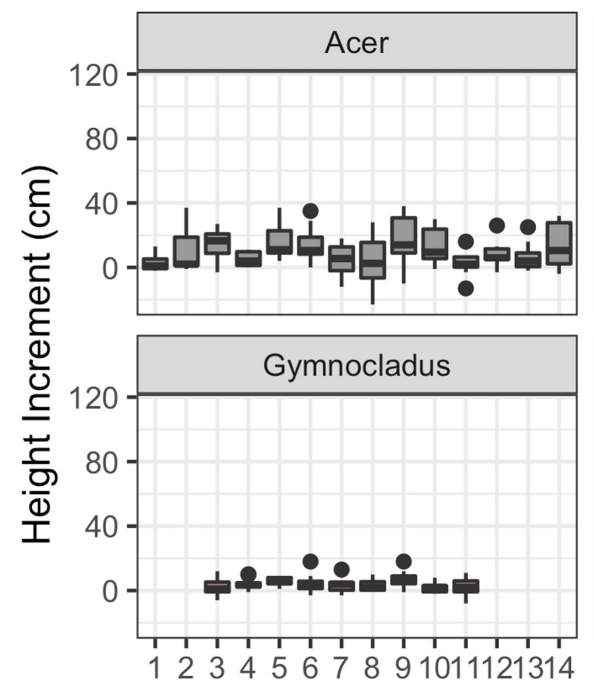

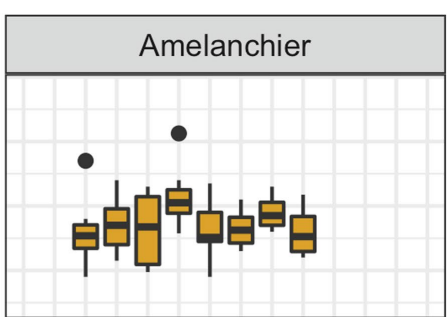

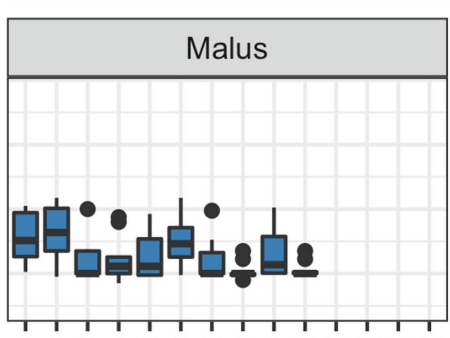

1234567891011121314 Week Planted
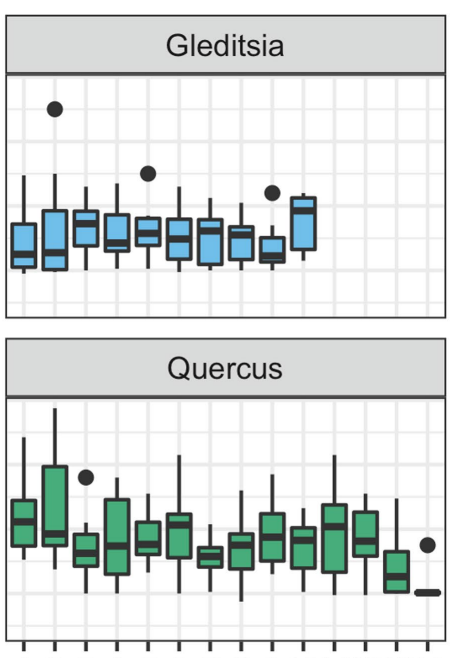

1234567891011121314

FIGURE 6 | Incremental height growth by the time of plantings. Height was measured for each tree at planting and in late fall 2020 and the difference is given here. Box plots show median, interquartile range, and minimum and maximum range for each week of planting. Negative height increments suggest die-back of the terminal stem. There was evidence of a significant effect of planting date on height growth for Malus and Quercus ( $p<0.01$; details in text and Table 3).

and survival. From the first measurements in mid-March, the stem water potential measurements in Gleditsia and Gymnocladus were below stem $P_{50}$, as determined by the hydraulic vulnerability curves. However, these trees grew without issue after outplanting. The stem water potential measurements for the remaining four cultivars did not exceed stem $P_{50}$ values. Though there was a negative relationship between Amelanchier and planting date, there were not detrimental effects observed in the growth of this cultivar.

For this experiment, the recovery of the hydraulic system in conjunction with spring growth is particularly important. The loss of stem hydraulic conductance during winter may not impact growth in all species, particularly ring-porous species. Spring recovery of hydraulic function can occur with growth of new xylem vessels and possibly by refilling of embolized conduits (Christensen-Dalsgaard and Tyree, 2014). Some trees can experience over 90\% PLC by early spring, but regain stem conductance following leaf expansion and earlywood growth (Jaquish and Ewers, 2001; Christensen-Dalsgaard and Tyree, 2014). In ring-porous species, including the Gymnocladus, Gleditsia, and Quercus cultivars in this experiment, building a new tree ring in the spring allows for full recovery of hydraulic conductance (Urli et al., 2012). This is likely the reason that Gymnocladus and Gleditsia grew without issue after planting, despite experiencing stem water potentials in cold storage that exceeded $P_{50}$.

However, the growth of new xylem is not the only strategy for hydraulic recovery. Diffuse-porous trees, represented by the Malus, Acer, and Amelanchier cultivars in this experiment, are more likely to rely on the development of positive xylem pressure for spring recovery of hydraulic conductivity (Hacke and Sauter, 1996; Niu et al., 2017). Trees held in cold storage maintained at a constant temperature may miss seasonal temperature changes that initiate physical processes that create xylem pressure (Schenk et al., 2021). Additionally, trees kept in storage before planting do not have access to soil water for the creation of positive root pressure, which can contribute to hydraulic recovery (Zhu et al., 2000; Jaquish and Ewers, 2001). Therefore, diffuse-porous trees might be particularly susceptible to damage if physiological thresholds are crossed in cold storage. In orchard settings, Malus cultivars at $70 \%$ PLC mid-winter had subsequent damage and die-back (Beikircher et al., 2016). High winter PLC in peach (Prunus persica Batsch) trees led to low rates of bud break as well as arrested growth of new shoots (Améglio et al., 2002). The Malus grown in our experiment experienced frequent terminal stem die-back. However, we did not observe a relationship between tip mortality and planting dates.

There is evidence to suspect that cultivated plants could be more vulnerable to hydraulic failure than wild-type species (Beikircher et al., 2013). Nursery practices, such as fertilization and irrigation, can change the xylem anatomy of plants, which impacts hydraulic function and vulnerability (Beikircher et al., 2019; Sloan et al., 2020). Grafting, rootstock choice, and selection for traits such as rapid growth will affect tree vigor, anatomy, and subsequently, hydraulic physiology and vulnerability to embolism (Beikircher et al., 2013). Plant growth is pushed in nursery production because larger plants are more valuable. Yet rapid growth, especially late-season, is less suberized and more at risk of desiccation than earlyseason growth and is more vulnerable to hydraulic failure (Beikircher and Mayr, 2013).

As was generally the case with stem water potential, we saw no trend in stem water content over the extended time in storage. Desiccation in cold storage represents a threat to nursery-grown trees, given the importance of stem water 
content to tree growth after planting. Through the winter, stem tissues can lose up to half of their water content, impacting the onset of water stress (Charrier et al., 2015). Many storage rooms in nursery production systems are essentially very large refrigerators and do not have humidity controls. A common practice is for growers to occasionally spray the plants with a hose or mulch with wetted shredded paper. Both methods are imprecise and can lead to desiccating conditions. Even though we did not see detrimental effects for the trees in this experiment, we still recommend nursery growers monitor the water content of roots and stems during the time in storage to track tree status. Water is needed in the stem before bud break for starch hydrolysis, cell growth, cell expansion, and the resumption of water flow through the stem if conductance has been lost (Améglio et al., 2002; Copini et al., 2019). Water is also necessary for mobilizing non-structural carbohydrates (NSC) reserves for survival and growth, another crucial component of winter survival (Tomasella et al., 2017). During the growing season, water stored in roots, branches, and leaves can buffer xylem tensions created by water stress and help preserve hydraulic function (Scholz et al., 2011; Cuneo et al., 2016; Knipfer et al., 2019); stored water during the dormant season may play a similar buffering role.

We did not see a consistent trend in total NSC concentrations among the cultivars for the time intervals at which we measured NSC. In the two cultivars where there was evidence of a significant effect of planting date on total NSC, yet the trends were contradictory, with a positive relationship between the metrics for Amelanchier and a negative relationship for Gymnocladus. While there are known methodological challenges to NSC measurements, the results reported here originate from one lab, allowing us to compare among them (Landhäusser et al., 2018). The expected pattern of NSC reserves through the winter starts with high levels at the end of the growing season, then a slow decline through the dormant season to meet respiratory demands, with a final rapid decline at leaf-out or earlywood formation (Dietze et al., 2014). Predictably, the starting NSC condition for plants in storage is an important factor for the carbon dynamics over time in storage (Christiaens et al., 2015). Extended time in cold storage means additional energy demands for maintenance respiration, which can impair outplanting performance (Cannell et al., 1990; Villar-Salvador et al., 2015). NSC was first measured in early spring, when the first trees were removed from cold storage and planted, so we did not capture the expected peak NSC concentration. Future studies on carbon dynamics in these cultivars would benefit from NSC measurements when trees are first put into storage.

In this experiment, the soluble sugars and starch concentrations were highly variable for all cultivars. The balance of starch and soluble sugars is also expected to shift over the dormant season: starch acts as a reservoir of energy for future use, while soluble sugars are used to perform immediate functions such as osmoregulation (Martínez-Vilalta et al., 2016). While reduced NSC levels may not be the ultimate cause of mortality, they can contribute to weakened trees that succumb to other stresses (Charrier et al., 2015). NSC reserves may have an osmotic role in stem pressure formation that leads to hydraulic recovery (Strati et al., 2003; Améglio et al., 2004; Yin et al., 2018; Zhang et al., 2018). Carbon depletion can also contribute to reduced water stress tolerance and slower resumption of growth (Jiang et al., 1995). Seedlings and saplings start with relatively small NSC reserves going into the dormant season, putting them at higher risk of mortality (Losso et al., 2018). On top of that, nursery trees face unique risks: pruning at the time of nursery lifting removes NSC sinks in the roots and branches (Charrier et al., 2015). If trees survive until planting, concerns about NSC reserves lessen: the leaves of deciduous trees can become autonomous from stored $\mathrm{C}$ reserves soon after bud break and do not rely on stored carbohydrates for long (Hoch et al., 2003).

Nursery-grown trees are important not only for the horticultural industry but also, in tree planting projects, one of our best solutions for addressing climate change (Bastin et al., 2019). Maintaining urban forests, wildland restoration, and reforestation are challenged by the environmental conditions associated with climate change, like extreme heatwaves, that make it more difficult for trees to survive after planting. Warm autumn temperatures delay dormancy and planting windows are more unpredictable (Beil et al., 2021; Fargione et al., 2021). Extreme weather puts even more pressure on nursery professionals to understand how plant physiology, including water relations and carbon dynamics, responds to each stage of the nursery production process (Sheridan and Nackley, 2021). An understanding of plant hydraulic physiology will also guide decisions about how to manage tree production and planting under warmer, drier future climate conditions (Losso et al., 2018). While we were not able to identify specific physiological thresholds or trends among the deciduous cultivars we tracked in this experiment, we present the first hydraulic response to cold storage data for these important genera and demonstrate how plant physiology can be integrated into nursery practices to guide plant production.

\section{DATA AVAILABILITY STATEMENT}

The raw data supporting the conclusions of this article will be made available by the authors, without undue reservation.

\section{AUTHOR CONTRIBUTIONS}

RS and LN: conceptualization, investigation, methodology, writing original draft, and writing-review and editing. RS: formal analysis and data curation. LN: funding acquisition. All authors contributed to the article and approved the submitted version.

\section{FUNDING}

Funding for this project was provided in part by the Oregon Association of Nurseries and the Oregon Department of Agriculture nursery research program grant no. K11920. 


\section{ACKNOWLEDGMENTS}

We thank Brian Hill, Dean and Louis Nackley, Luke and Owen Van Lehman, and Hannah Velazquez for assistance with project installation, field maintenance, and data collection.

\section{REFERENCES}

Adams, H. D., Zeppel, M. J. B., Anderegg, W. R. L., Hartmann, H., Landhäusser, S. M., Tissue, D. T., et al. (2017). A multi-species synthesis of physiological mechanisms in drought-induced tree mortality. Nat. Ecol. Evol. 1, 1285-1291. doi: 10.1038/s41559-017-0248-x

AgriMet (2016). Aurora, Oregon AgriMet Weather Station (arao) Available at: https://www.usbr.gov/pn/agrimet/agrimetmap/araoda.html. (Accessed May 31, 2021).

Améglio, T., Bodet, C., Lacointe, A., and Cochard, H. (2002). Winter embolism, mechanisms of xylem hydraulic conductivity recovery and springtime growth patterns in walnut and peach trees. Tree Physiol. 22, 1211-1220. doi: 10.1093/ treephys/22.17.1211

Améglio, T., Decourteix, M., Alves, G., Valentin, V., Sakr, S., Julien, J. L., et al. (2004). Temperature effects on xylem sap osmolarity in walnut trees: evidence for a vitalistic model of winter embolism repair. Tree Physiol. 24, 785-793. doi: 10.1093/treephys/24.7.785

Bastin, J.-F., Finegold, Y., Garcia, C., Mollicone, D., Rezende, M., Routh, D., et al. (2019). The global tree restoration potential. Science 365, 76-79. doi: 10.1126/science.aax0848

Beikircher, B., De Cesare, C., and Mayr, S. (2013). Hydraulics of high-yield orchard trees: A case study of three Malus domestica cultivars. Tree Physiol. 33, 1296-1307. doi: 10.1093/treephys/tpt096

Beikircher, B., Losso, A., Gemassmer, M., Jansen, S., and Mayr, S. (2019). Does fertilization explain the extraordinary hydraulic behaviour of apple trees? J. Exp. Bot. 70, 1915-1925. doi: 10.1093/jxb/erz070

Beikircher, B., and Mayr, S. (2013). Winter peridermal conductance of apple trees: Lammas shoots and spring shoots compared. Trees Struct. Funct. 27, 707-715. doi: 10.1007/s00468-012-0826-0

Beikircher, B., Mittmann, C., and Mayr, S. (2016). Prolonged soil frost affects hydraulics and phenology of apple trees. Front. Plant Sci. 7:867. doi: 10.3389/ fpls.2016.00867

Beil, I., Kreyling, J., Meyer, C., Lemcke, N., and Malyshev, A. V. (2021). Late to bed, late to rise-warmer autumn temperatures delay spring phenology by delaying dormancy. Glob. Chang. Biol. 27, 5806-5817. doi: 10.1111/ gcb. 15858

Cannell, M. G. R., Tabbush, P. M., Deans, J. D., Hollingsworth, M. K., Sheppard, L. J., Philipson, J. J., et al. (1990). Sitka spruce and Douglas fir seedlings in the nursery and in cold storage: root growth potential, carbohydrate content, dormancy, frost hardiness and mitotic index. Forestry 63, 9-27. doi: 10.1093/forestry/63.1.9

Cavender-Bares, J., and Holbrook, N. M. (2001). Hydraulic properties and freezing-induced cavitation in sympatric evergreen and deciduous oaks with contrasting habitats. Plant Cell Environ. 24, 1243-1256. doi: 10.1046/j.13653040.2001.00797.x

Charrier, G., Ngao, J., Saudreau, M., and Améglio, T. (2015). Effects of environmental factors and management practices on microclimate, winter physiology, and frost resistance in trees. Front. Plant Sci. 6:259. doi: 10.3389/ fpls.2015.00259

Chmura, D. J., Anderson, P. D., Howe, G. T., Harrington, C. A., Halofsky, J. E., Peterson, D. L., et al. (2011). Forest responses to climate change in the northwestern United States: Ecophysiological foundations for adaptive management. For. Ecol. Manag. 261, 1121-1142. doi: 10.1016/j.foreco.2010. 12.040

Choat, B., Brodribb, T. J., Brodersen, C. R., Duursma, R. A., López, R., and Medlyn, B. E. (2018). Triggers of tree mortality under drought. Nature 558, 531-539. doi: 10.1038/s41586-018-0240-x

Christensen-Dalsgaard, K. K., and Tyree, M. T. (2014). Frost fatigue and spring recovery of xylem vessels in three diffuse-porous trees in situ. Plant Cell Environ. 37, 1074-1085. doi: 10.1111/pce.12216
Thanks to Hans Nelson \& Sons Nursery and Bailey Nurseries for providing plant material. Special thanks to Sam, Rich, and Claudia, and the rest of the team at J. Frank Schmidt and Son Co. for donating plant material and providing cooler space to store trees.

Christiaens, A., De Keyser, E., Lootens, P., Pauwels, E., Roldán-Ruiz, I., De Riek, J., et al. (2015). Cold storage to overcome dormancy affects the carbohydrate status and photosynthetic capacity of Rhododendron simsii. Plant Biol. 17, 97-105. doi: 10.1111/plb.12195

Cochard, H., and Tyree, M. T. (1990). Xylem dysfunction in Quercus: vessel sizes, tyloses, cavitation and seasonal changes in embolism. Tree Physiol. 6, 393-407. doi: 10.1093/treephys/6.4.393

Copini, P., Vergeldt, F. J., Fonti, P., Sass-Klaassen, U., Den Ouden, J., Sterck, F., et al. (2019). Magnetic resonance imaging suggests functional role of previous year vessels and fibres in ring-porous sap flow resumption. Tree Physiol. 39, 1009-1018. doi: 10.1093/treephys/tpz019

Cuneo, I. F., Knipfer, T., Brodersen, C. R., and McElrone, A. J. (2016). Mechanical failure of fine root cortical cells initiates plant hydraulic decline during Drought. Plant Physiol. 172, 1669-1678. doi: 10.1104/pp.16.00923

Deans, J. D., Lundberg, C., Tabbush, P. M., Cannell, M. G. R., Sheppard, L. J., and Murray, M. B. (1990). The influence of desiccation, rough handling and cold storage on the quality and establishment of Sitka spruce planting stock. Forestry 63, 129-141. doi: 10.1093/forestry/63.2.129

Dietze, M. C., Sala, A., Carbone, M. S., Czimczik, C. I., Mantooth, J. A., Richardson, A. D., et al. (2014). Nonstructural carbon in Woody plants. Annu. Rev. Plant Biol. 65, 667-687. doi: 10.1146/annurev-arplant-050213-040054

Dumroese, R. K., Landis, T. D., Pinto, J. R., Haase, L., Wilkinson, K. W., and Davis, A. S. (2016). Meeting forest restoration challenges: using the target plant concept. Reforesta 1, 37-52. doi: 10.21750/REFOR.1.03.3

Duursma, R., and Choat, B. (2017). Fitplc - an R package to fit hydraulic vulnerability curves. J. Plant Hydraul. 4:e002. doi: 10.20870/jph.2017.e002

Fargione, J., Haase, D. L., Burney, O. T., Kildisheva, O. A., Edge, G., Cook-Patton, S. C., et al. (2021). Challenges to the reforestation pipeline in the United States. Front. For. Glob. Chang. 4:629198. doi: 10.3389/ffgc.2021. 629198

Galvez, D. A., Landhäusser, S. M., and Tyree, M. T. (2011). Root carbon reserve dynamics in aspen seedlings: does simulated drought induce reserve limitation? Tree Physiol. 31, 250-257. doi: 10.1093/treephys/tpr012

Grossnickle, S. C., Kiiskila, S. B., and Haase, D. L. (2020). Seedling ecophysiology: five questions to explore in the nursery for optimizing subsequent field success. Tree Plant. Notes 63, 112-127.

Haase, D. L., Pike, C., and Enebak, S. (2020). Forest nursery seedling production in the United States - fiscal year 2019. Tree Plant. Notes 63, 26-31.

Hacke, U., and Sauter, J. J. (1996). Xylem dysfunction during winter and recovery of hydraulic conductivity in diffuse-porous and ring-porous trees. Oecologia 105, 435-439. doi: 10.1007/BF00330005

Harris, J. R., Bassuk, N. L., and Whitlow, T. H. (1993). Effect of cold storage on bud break, root regeneration and shoot extension of Douglas fir, paper birch and green ash. J. Environ. Hortic. 11, 119-123. doi: 10.24266/07382898-11.3.119

Hoch, G., Richter, A., and Körner, C. (2003). Non-structural carbon compounds in temperate forest trees. Plant Cell Environ. 26, 1067-1081. doi: 10.1046/j. 0016-8025.2003.01032.x

InsideWood (2004). InsideWood. Available at: http://insidewood.lib.ncsu.edu/ search. (Accessed June 27, 2021).

Jacobs, D. F., Wilson, B. C., Ross-Davis, A. L., and Davis, A. S. (2008). Cold hardiness and transplant response of Juglans nigra seedlings subjected to alternative storage regimes. Ann. For. Sci. 65, 606-606. doi: 10.1051/ forest:2008036

Jaquish, L. L., and Ewers, F. W. (2001). Seasonal conductivity and embolism in the roots and stems of two clonal ring-porous trees, Sassafras albidum (Lauraceae) and Rhus typhina (Anacardiaceae). Am. J. Bot. 88, 206-212. doi: $10.2307 / 2657011$

Jiang, Y., MacDonald, S. E., and Zwiazek, J. J. (1995). Effects of cold storage and water stress on water relations and gas exchange of white spruce (Picea glauca) seedlings. Tree Physiol. 15, 267-273. doi: 10.1093/treephys/15.4.267 
Knipfer, T., Reyes, C., Earles, J. M., Berry, Z. C., Johnson, D. M., Brodersen, C. R., et al. (2019). Spatiotemporal coupling of vessel cavitation and discharge of stored xylem water in a tree sapling. Plant Physiol. 179, 1658-1668. doi: 10.1104/pp.18.01303

Landhäusser, S. M., Chow, P. S., Turin Dickman, L., Furze, M. E., Kuhlman, I., Schmid, S., et al. (2018). Standardized protocols and procedures can precisely and accurately quantify non-structural carbohydrates. Tree Physiol. 38, 1764-1778. doi: 10.1093/treephys/tpy118

Landsberg, J. J., and Waring, R. H. (2017). Water relations in tree physiology: where to from here? Tree Physiol. 37, 18-32. doi: 10.1093/treephys/ tpw102

Leyva, A., Quintana, A., Sánchez, M., Rodríguez, E. N., Cremata, J., and Sánchez, J. C. (2008). Rapid and sensitive anthrone-sulfuric acid assay in microplate format to quantify carbohydrate in biopharmaceutical products: method development and validation. Biologicals 36, 134-141. doi: 10.1016/j. biologicals.2007.09.001

Losso, A., Bär, A., Dämon, B., Dullin, C., Ganthaler, A., Petruzzellis, F., et al. (2018). Insights from in vivo micro-CT analysis: testing the hydraulic vulnerability segmentation in Acer pseudoplatanus and Fagus sylvatica seedlings. New Phytol. 221, 1831-1842. doi: 10.1111/nph.15549

Maclennan, L., and Fennessy, J. (2006). Plant Quality A Key to Success in Forest Establishment. Proceedings of the COFORD Conference, 20-21 September 2005, Mount Wolseley Hotel, Tullow, Co Carlow.

Martínez-Vilalta, J., Sala, A., Asensio, D., Galiano, L., Hoch, G., Palacio, S., et al. (2016). Dynamics of non-structural carbohydrates in terrestrial plants: A global synthesis. Ecol. Monogr. 86, 495-516. doi: 10.1002/ ecm.1231

McKay, H. M. (1994). Frost hardiness and cold-storage tolerance of the root system of Picea sitchensis, Pseudotsuga menziesii, Larix kaempferi and Pinus sylvestris bare-root seedlings. Scand. J. For. Res. 9, 203-213. doi: 10.1080/ 02827589409382832

Mckay, H. M. (1997). A review of the effect of stresses between lifting and planting on nursery stock quality and performance. New For. 13, 363-393. doi: 10.1023/A:1006563130976

Mena-Petite, A., Ortega-Lasuen, U., González-Moro, M., Lacuesta, M., and Muñoz-Rueda, A. (2001). Storage duration and temperature effect on the functional integrity of container and bare-root Pinus radiata D. Don stocktypes. Trees-Struct. Funct. 15, 289-296. doi: 10.1007/s004680100104

Milliron, L., Olivos, A., Saa, S., Sanden, B. L., and Shackel, K. A. (2018). Dormant stem water potential responds to laboratory manipulation of hydration as well as contrasting rainfall field conditions in deciduous tree crops. Biosyst. Eng. 165, 2-9. doi: 10.1016/j.biosystemseng.2017. 09.001

Nanninga, C., Buyarski, C. R., Pretorius, A. M., and Montgomery, R. A. (2017). Increased exposure to chilling advances the time to budburst in north American tree species. Tree Physiol. 37, 1727-1738. doi: 10.1093/treephys/ tpx136

Niu, C. Y., Meinzer, F. C., and Hao, G. Y. (2017). Divergence in strategies for coping with winter embolism among co-occurring temperate tree species: the role of positive xylem pressure, wood type and tree stature. Funct. Ecol. 31, 1550-1560. doi: 10.1111/1365-2435.12868

Overton, E. C., Davis, A. S., and Pinto, J. R. (2013). Insights into big sagebrush seedling storage practices. Nativ. Plants J. 14, 225-230. doi: 10.3368/ npj.14.3.225

Ritchie, G. A. (1982). Carbohydrate reserves and root growth potential in Douglas-fir seedlings before and after cold storage. Can. J. For. Res. 12, 905-912. doi: 10.1017/CBO9781107415324.004

Schenk, H. J., Jansen, S., and Hölttä, T. (2021). Positive pressure in xylem and its role in hydraulic function. New Phytol. 230, 27-45. doi: 10.1111/ nph. 17085

Scholz, F. G., Phillips, N., Bucci, S. J., Meinzer, F. C., and Goldstein, G. (2011). "Hydraulic Capacitance: Biophysics and Functional Significance of Internal Water Sources in Relation to Tree Size," in Size- and Age-Related Changes in Tree Structure and Function. eds. F. C. Meinzer, B. Lachenbruch and T. E. Dawson (New York: Springer), 341-384.

Sevanto, S., McDowell, N. G., Dickman, L. T., Pangle, R., and Pockman, W. T. (2014). How do trees die? A test of the hydraulic failure and carbon starvation hypotheses. Plant Cell Environ. 37, 153-161. doi: 10.1111/ pce. 12141
Sheridan, R. A., and Nackley, L. L. (2021). A primer on plant hydraulic physiology for nursery professionals. Tree Plant. Notes 64, 70-79.

Sloan, J. L., Burney, O. T., and Pinto, J. R. (2020). Drought-conditioning of quaking Aspen (Populus tremuloides Michx.) seedlings During nursery production modifies seedling anatomy and physiology. Front. Plant Sci. 11:557894. doi: $10.3389 /$ fpls.2020.557894

Smith, D. D. (2018). Conduct R. Available at: https://uwmadison.app.box.com/v/ conductR. (Accessed March 1, 2020).

Sperry, J. S., and Love, D. M. (2015). What plant hydraulics can tell us about responses to climate-change droughts. New Phytol. 207, 14-27. doi: 10.1111/ nph.13354

Sperry, J. S., and Saliendra, N. (1994). Intra-and inter-plant variation in xylem cavitation in Betula occidentalis. Plant Cell Environ. 17, 1233-1241. doi: 10.1111/j.1365-3040.1994.tb02021.x

Strati, S., Patiño, S., Slidders, C., Cundall, E. P., and Mencuccini, M. (2003). Development and recovery from winter embolism in silver birch: seasonal patterns and relationships with the phenological cycle in oceanic Scotland. Tree Physiol. 23, 663-673. doi: 10.1093/treephys/23.10.663

Tixier, A., Gambetta, G. A., Godfrey, J., Orozco, J., and Zwieniecki, M. A. (2019). Non-structural carbohydrates in dormant Woody perennials; The tale of winter survival and spring arrival. Front. For. Glob. Chang. 2:18. doi: $10.3389 /$ ffgc. 2019.00018

Tomasella, M., Häberle, K. H., Nardini, A., Hesse, B., Machlet, A., and Matyssek, R. (2017). Post-drought hydraulic recovery is accompanied by non-structural carbohydrate depletion in the stem wood of Norway spruce saplings. Sci. Rep. 7, 14308-14313. doi: 10.1038/s41598-017-14645-w

Tung, C.-H., Wisniewski, L., and DeYoe, D. (1986). Effects of prolonged cold storage on phenology and performance of Douglas-fir and noble fir $2+0$ seedlings from high-elevation sources. Can. J. For. Res. 16, 471-475. doi: $10.1139 / \mathrm{x} 86-084$

U.S. Drought Monitor (2021). Available at: https://droughtmonitor.unl.edu/. (Accessed May 31, 2021).

U.S.A. National Phenology Network (NPN). (2020). Phenology Visualization Tool. Available at: https://www.usanpn.org/data/visualizations. (Accessed May 31, 2021).

United State Department of Agriculture (USDA) (2020). 2019 Census of Horticultural Specialties. Available at: https://www.nass.usda.gov/Publications/ AgCensus/2017/Online_Resources/Census_of_Hortculture_Specialties/ HORTIC.pdf. (Accessed October 31, 2021).

Urli, M., Porté, A. J., Cochard, H., Guengant, Y., Burlett, R., and Delzon, S. (2012). Xylem embolism threshold for catastrophic hydraulic failure in angiosperm trees. Tree Physiol. 33, 672-683. doi: 10.1093/treephys/ tpt030

Villar-Salvador, P., Uscola, M., and Jacobs, D. F. (2015). The role of stored carbohydrates and nitrogen in the growth and stress tolerance of planted forest trees. New For. 46, 813-839. doi: 10.1007/s11056-015-9499-z

Wheeler, E. A. (2011). InsideWood - a web resource for hardwood anatomy. IAWA J. 32, 199-211. doi: 10.1163/22941932-90000051

Yin, X. H., Sterck, F., and Hao, G. Y. (2018). Divergent hydraulic strategies to cope with freezing in co-occurring temperate tree species with special reference to root and stem pressure generation. New Phytol. 219, 530-541. doi: $10.1111 / \mathrm{nph} .15170$

Zhang, W., Feng, F., and Tyree, M. T. (2018). Seasonality of cavitation and frost fatigue in Acer mono maxim. Plant Cell Environ. 41, 1278-1286. doi: $10.1111 /$ pce. 13117

Zhu, X. B., Cox, R. M., and Arp, P. A. (2000). Effects of xylem cavitation and freezing injury on dieback of yellow birch (Betula alleghaniensis) in relation to a simulated winter thaw. Tree Physiol. 20, 541-547. doi: 10.1093/ treephys/20.8.541

Conflict of Interest: The authors declare that the research was conducted in the absence of any commercial or financial relationships that could be construed as a potential conflict of interest.

Publisher's Note: All claims expressed in this article are solely those of the authors and do not necessarily represent those of their affiliated organizations, or those of the publisher, the editors and the reviewers. Any product that may be evaluated in this article, or claim that may be made by its manufacturer, is not guaranteed or endorsed by the publisher. 
Copyright (C) 2022 Sheridan and Nackley. This is an open-access article distributed under the terms of the Creative Commons Attribution License (CC BY). The use, distribution or reproduction in other forums is permitted, provided the original author(s) and the copyright owner(s) are credited and that the original publication in this journal is cited, in accordance with accepted academic practice. No use, distribution or reproduction is permitted which does not comply with these terms. 